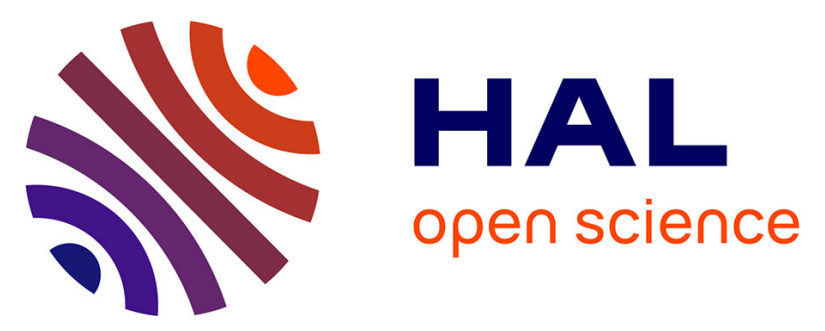

\title{
Improving pork quality traits by a short-term dietary methionine supplementation at levels above growth requirements in finisher pigs
}

Bénédicte Lebret, Dolores I. Batonon-Alavo, Marie-Hélène Perruchot, Yves Mercier, Florence Gondret

\section{To cite this version:}

Bénédicte Lebret, Dolores I. Batonon-Alavo, Marie-Hélène Perruchot, Yves Mercier, Florence Gondret. Improving pork quality traits by a short-term dietary methionine supplementation at levels above growth requirements in finisher pigs. Meat Science, 2018, 145, pp.230-237. 10.1016/j.meatsci.2018.06.040 . hal-01827949

\section{HAL Id: hal-01827949 https://hal.science/hal-01827949}

Submitted on 26 May 2020

HAL is a multi-disciplinary open access archive for the deposit and dissemination of scientific research documents, whether they are published or not. The documents may come from teaching and research institutions in France or abroad, or from public or private research centers.
L'archive ouverte pluridisciplinaire HAL, est destinée au dépôt et à la diffusion de documents scientifiques de niveau recherche, publiés ou non, émanant des établissements d'enseignement et de recherche français ou étrangers, des laboratoires publics ou privés. 


\section{Accepted Manuscript}

Improving pork quality traits by a short-term dietary hydroxy methionine supplementation at levels above growth requirements in finisher pigs

Bénédicte Lebret, Dolores I. Batonon-Alavo, Marie-Hélène Perruchot, Yves Mercier, Florence Gondret

PII: S0309-1740(18)30550-3

DOI: doi:10.1016/j.meatsci.2018.06.040

Reference: MESC 7613

To appear in:

Meat Science

Received date:

29 May 2018

Revised date:

18 June 2018

Accepted date:

28 June 2018

Please cite this article as: Bénédicte Lebret, Dolores I. Batonon-Alavo, Marie-Hélène Perruchot, Yves Mercier, Florence Gondret, Improving pork quality traits by a shortterm dietary hydroxy methionine supplementation at levels above growth requirements in finisher pigs. Mesc (2018), doi:10.1016/j.meatsci.2018.06.040

This is a PDF file of an unedited manuscript that has been accepted for publication. As a service to our customers we are providing this early version of the manuscript. The manuscript will undergo copyediting, typesetting, and review of the resulting proof before it is published in its final form. Please note that during the production process errors may be discovered which could affect the content, and all legal disclaimers that apply to the journal pertain. 
Improving pork quality traits by a short-term dietary hydroxy methionine supplementation at levels above growth requirements in finisher pigs

Bénédicte LEBRET ${ }^{\mathrm{a}}$, Dolores I. BATONON-ALAVO ${ }^{\mathrm{b}}$, Marie-Hélène PERRUCHOT ${ }^{\mathrm{a}}$, Yves MERCIER $^{\mathrm{b}}$, Florence GONDRET ${ }^{\mathrm{a}}$

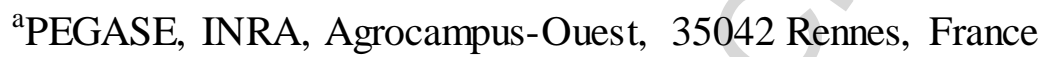

${ }^{\mathrm{b}}$ ADISSEO France SAS, CERN, 03600 Commentry, France

Corresponding author: Benedicte.Lebret@inra.fr 


\begin{abstract}
The effects of dietary methionine (Met) supplies above growth requirements on tissue biology and pork quality were studied. At $70 \mathrm{~kg}, 45$ crossbred pigs were fed a control (CONT) diet adequate in Met $(0.22 \%$ Met) up to $105 \mathrm{~kg}$. For the last 14 days before slaughter, pigs were fed with the CONT diet or with diets where the Met level was increased to Met3 (0.66\% Met) or Met5 (1.10\% Met). Growth performance and carcass composition did not change with the treatment. Pigs fed the Met5 treatment displayed lower TBARS and higher glutathione levels $(\mathrm{P} \leq 0.05)$, along with higher ultimate $\mathrm{pH}(\mathrm{P}<0.01)$ and lower drip, lightness and hue $(\mathrm{P} \leq$ 0.10) in the longissimus muscle, compared to the CONT and Met3 pigs. Extra-dietary Met improved ham's technological quality in the Met3 and Met5 groups $(\mathrm{P} \leq 0.05)$. Thus, dietary Met supplementation improves pork quality without impairing growth or carcass traits.
\end{abstract}

Keywords: amino acid; HMTBA; muscle; glutathione; antioxidant capacity; technological quality 


\section{Introduction}

Methionine (Met) is an essential amino acid (AA) sustaining growth and development. In young growing pigs, dietary Met deficiency decreased growth rate and protein accretion (Conde-Aguilera, Barea, Le Floc'h, Lefaucheur, \& van Milgen, 2010; Conde-Aguilera et al., 2016a) and this was associated with greater lipid deposition in carcass and muscle (Castellano et al., 2015). In finishing pigs, dietary Met deficiency also resulted in higher muscle glycolytic potential (Conde-Aguilera, Cobo-Ortega, Mercier, Tesseraud, \& van Milgen, 2014). Altogether, changes in muscle energy storages (lipid and glycogen) with dietary Met supply may subsequently influence some meat quality traits, including the extent of postmortem (p.m.) pH decline. Importantly, Met also shows non-proteinogenic functions (Tesseraud, Métayer-Coustard, Collin, \& Seiliez, 2009). Specifically, Met is the precursor of cysteine, which is essential for the synthesis of glutathione and taurine, two major cellular non-enzymatic antioxidants. Oxidative stresses occur all along the value chain of animal production including meat storage, with consequences on juiciness, tenderness, flavour and warmed-over flavor, odour and rancidity of products (Lund, Lametsch, Hviid, Jensen, \& Skibsted, 2007). However, oxidation processes may be delayed, retarded or even prevented by applying an antioxidant strategy such as vitamin E and(or) selenium (Shahidi \& Wanasundara, 1992). In young pigs, dietary Met deficiency reduced the amount of glutathione in the liver and muscle, resulting in an elevation of antioxidant enzyme activity in the muscle and adipose tissues (Castellano et al., 2015; Conde-Aguilera et al., 2016a). Conversely, Met supplementation, especially when provided in the form of 2-hydroxy-4 (methylthio) butanoic acid (HMTBA) that leads to a higher synthes is of cysteine, taurine and reduced glutathione than DL-Met with additional benefits in terms of antioxidant capacities (Martin-Venegas, Geraert, \& Ferrer, 2006; Zhang, Li, \& Wang, 2015; Vazquez-Anon, Bertin, Mercier, Reznik, \& Roberton, 2017), may thus modify tissues' protective capacities through glutathione 
synthesis. Therefore, the question arises whether HMTBA might also help to prevent oxidative stress and delay p.m. oxidation processes in pork when supplied in pig diet beyond growth requirements, with possible consequences for meat quality traits such as water-holding capacity (Huff-Lonergan \& Lonergan, 2005) or colour stability during storage.

To date, very few studies have however considered the effects of dietary Met at levels above growth requirements and its consequences on muscle composition and meat quality traits. Recently, Li et al. (2017) reported that low-birth-weight piglets receiving L-Metsupplemented diets above the standard requirement from $40 \mathrm{~kg}$ up to slaughter at $100 \mathrm{~kg}$ of body weight (BW) exhibited increased muscular glutathione and lower lipid peroxidation, with positive effects on pork quality (higher ultimate $\mathrm{pH}$ and reduced drip loss during loin meat storage) when compared with pigs fed a control diet. Moreover, chickens fed HMTBAsupplemented diet had greater glutathione levels and reduced lipid peroxidation, compared to those receiving a DL-Met-supplemented diet (Swennen et al., 2011).

Considering this information altogether, we hypothesized that a short-term dietary Met supplementation (as HMTBA) in finishing pigs may influence muscle energy stores and antioxidant capacity and thereby potentially influence pork quality traits, without impairing growth performance or carcass composition. This study aimed at determining the effects of dietary HMTBA supply at levels largely above total sulfur amino acid requirements during the last two weeks before slaughter on growth performance, body composition and muscle biochemical properties at slaughter and meat quality in pigs.

\section{Material and methods}

\subsection{Experimental design, Diets and Management}

The experiment was performed in the INRA experimental facilities (UEPR, 35590 SaintGilles, France) in compliance with European Union (directive 86/609/CEE) and French 
legislation (Décret n²001-464 29/05/01; agreement for animal housing number C-35-27532). The technical and scientific staffs had individual accreditation from the French Minister to experiment on living animals. At approximately $70 \mathrm{~kg}$ of BW, 45 crossbred ((Large WhitexLandrace) $\times$ Piétrain) female pigs free of the halothane-sensitive (n) and $\mathrm{RN}^{-}$alleles were chosen from 15 litters and assigned in-litter to 3 dietary treatments ( $n=15 /$ group). They were all housed in individual pens $(85 \times 265 \mathrm{~cm})$ placed in the same room on a concrete floor. They were first fed a control diet (CONT) formulated to meet nutritional requirements based on NRC (2012) guidelines from $70 \mathrm{~kg}$ to $105 \mathrm{~kg}$ of BW. For the last fourteen days before slaughter, pigs were then fed either the control diet (CONT group) or an HMTBAsupplemented diet with a calculated Met value 3 times (Met3 group, 0.66\% Met) or 5 times (Met5 group, $1.10 \%$ Met) greater than that in the CONT diet (Table 1). Diets were isoenergetic and iso-nitrogenous. Their detailed composition are presented in Table 1. All pigs had free access to feed and water until the end of the experiment, i.e. $24 \mathrm{~h}$ before slaughter.

\subsection{Growth Performance}

Pigs were weighed individually at the beginning of the dietary treatment period, one week after its start and the day before slaughter. Individual feed consumption was measured weekly (feed offered minus refusals) during the test period. Average daily gain, average feed intake and feed conversion ratio (FCR) were calculated for each pig during the test period. Backfat thickness was measured at the last rib level on the left and right sides of the body by an ultrasound apparatus (VETKOPLUS, Noveko Inc., Boucherville, QC, Canada) on all pigs at the beginning and end of the test period.

\subsection{Slaughter and Carcass Measurements}

Pigs were conducted to the slaughterhouse (INRA, 35590 Saint-Gilles, France) in two 
successive batches at 1 -week intervals $(n=21$ and $n=24$ pigs for batches 1 and 2, respectively), with a balanced representation of the 3 dietary groups in each batch, with the heaviest pigs of each dietary group slaughtered in the first batch. All pigs fasted for 24 hours before slaughter. The day before slaughter, pigs from the same dietary group ( $n=7$ for batch 1 or $\mathrm{n}=8$ for batch 2 ) were loaded onto a lorry, transported together to the slaughterhouse (5 min) and kept in lairage in the same pen without mixing with pigs from the other groups. All pigs had free access to water. The next day, pigs were taken alternately from each group and slaughtered by electrical stunning $(350 \mathrm{~V}-4 \mathrm{~A})$ followed by jugular exsanguination in compliance with the current national regulations applied in slaughterhouses. Just after slaughter, the hot carcass (trimmed of digestive, reproductive, and respiratory tracts), the entire perirenal fat (around kidneys) and the liver were weighed. Carcass dressing was calculated as the ratio of hot carcass weight to final BW.

After $24 \mathrm{~h}$ of chilling at $4^{\circ} \mathrm{C}$, the weight of the cold carcass and of wholesale cuts from the right carcass side (ham, loin, backfat, shoulder and belly) were recorded. Carcass drip loss (using hot and cold carcass weights) and composition (percentage proportion of wholesale cuts to the right side) were calculated and used to determine lean meat content (LMC) according to the equation $\mathrm{LMC}(\%)=25.08+0.73 \%$ ham $+0.87 \%$ loin $-1.23 \%$ belly (Daumas, 2008).

\subsection{Tissue sampling and measurements of meat quality traits}

Just after evisceration (i.e. 12 minutes after exsanguination), liver samples were taken, immediately frozen in liquid nitrogen and stored at $-76^{\circ} \mathrm{C}$ until the determination of glutathione contents.

Thirty minutes after slaughter, samples of longissimus lumborum muscle (LM) were taken from the carcass's right side at the last rib level, cut into small pieces and immediately frozen 
in liquid nitrogen; samples were stored at $-76^{\circ} \mathrm{C}$ until determination of antioxidant capacity indicators, glycolytic potential and $\mathrm{pH} 1$. The latter was assessed with a $\mathrm{pH}$ meter equipped with a dedicated electrode (Ingold Xerolyte electrode, Metrohm pH-meter, Berlin, Germany) after homogenization of $2 \mathrm{~g}$ of muscle in $18 \mathrm{ml}$ of $5 \mathrm{mM}$ Na iodoacetate as described previously (Lebret et al., 2011).

Twenty-four hours after slaughter, $\mathrm{pH}$ was measured at $24 \mathrm{~h}$ directly in the $\mathrm{LM}$ (between $13^{\text {th }}$ and $14^{\text {th }}$ ribs) and in the ham muscles, namely Semimembranosus (SM), Gluteus medius (GM), Gluteus superficialis (GS) and Adductor(AD), using the same apparatus as above and with an automatic temperature compensation. Frequencies of loin samples exhibiting actual or trend for PSE $(\mathrm{pH} 30 \mathrm{~min} \leq 6.10)$ or acid meat $(\mathrm{pH} 24 \mathrm{~h} \leq 5.50)$ defects were calculated for each treatment group.

The same day, a transversal section of LM (second to last rib) was taken, trimmed of external fat, minced and homogenized. A sub-sample was stored at $-76^{\circ} \mathrm{C}$ before assessment of protein oxidation. Another sub-sample was freeze dried and pulverized before determination of protein and water content, and the remaining part was stored at $-20^{\circ} \mathrm{C}$ in a vacuum before complementary analyses for chemical composition. Another transversal section of LM was taken consecutively (cranial part) and bloomed for $15 \mathrm{~min}$ at $4^{\circ} \mathrm{C}$ under artificial light before measurement of color coordinates CIE L*: lightness, $\mathrm{a}^{*}$ : redness, $\mathrm{b}^{*}$ : yellowness, $\mathrm{C}^{*}$ : saturation (chroma) and $\mathrm{h}^{\circ}$ : hue (average values of 3 different determinations) using a chromameter Minolta CR 300 (Osaka, Japan) with a D65 illuminant, a 1-cm diameter aperture and a $2^{\circ}$ observer angle. The LM slices were then re-covered with an air-permeable plastic film and kept at $4^{\circ} \mathrm{C}$ under permanent indirect artificial light. It was checked at 4 and 7 days p.m. for additional color measurements. Samples were taken from these slices at 4 and 7 days p.m., minced and stored at $-76^{\circ} \mathrm{C}$ for determination of protein oxidation. A third slice of $\mathrm{LM}$ $\left(100 \pm 10 \mathrm{~g}\right.$, consecutive to the previous one) was taken, weighed and kept at $4^{\circ} \mathrm{C}$ in a plastic 
bag in hanging position for determination of drip loss at 4 and 7 days p.m. (Lebret et al., 2011).

The day after slaughter, color coordinates were also measured on the GS muscle as described above, and the GS's water-holding capacity (WHC) was assessed from the time needed for a calibrated piece of filter paper to become wet when put on the freshly cut surface of the muscle (Monin, Sellier, Ollivier, Goutefongea, \& Girard, 1981). This assessment allowed for calculation of the meat quality index (MQI), which is a predictor of the technological yield of cooked ham (Tribout \& Bidanel, 2000), using the equation: MQI $=-41+11.01(\mathrm{pH} 24 \mathrm{~h} \mathrm{SM})$ $-0.231\left(\mathrm{~L}^{*} \mathrm{GS}\right)+0.105(\mathrm{WHC} \mathrm{GS})$.

\subsection{Muscle Chemical Composition}

Protein content was determined from freeze-dried LM samples (duplicates) from the determination of nitrogen concentration (Dumas method, AOAC, 1990) with a Rapid N cube (Elementar, Villeurbanne, France) by using a multiplication factor of 6.25. Water content was determined in duplicates on freeze-dried LM samples before and after drying at $103^{\circ} \mathrm{C}$. Protein and water contents were expressed as percentage of fresh muscle considering water loss of each muscle sample during freeze-drying. Lipid content was determined on LM samples kept at $-20^{\circ} \mathrm{C}$ by chloroform-methanol (2:1 v/v) extraction (Folch, Lees, \& Stanley, 1957). Haeminic iron was measured according to Hornsey (1956) to determine the myoglobin content. Lipid and haeminic iron were determined within single assays.

Glycolytic potential, defined as GP $=2 *[($ glycogen $)+($ glucose $)+($ glucose- 6 -phosphate $)]+$ (lactate) and expressed as $\mu$ mole equivalent lactate/g of fresh tissue (Monin \& Sellier, 1985), was determined in LM sampled $30 \mathrm{~min}$ p.m. Concentrations in lactate (lactate PAP, Biomerieux, Marcy l'Etoile, France), glucose and glucose-6-phosphate altogether (glucose HK, ABX Diagnostics kit, Montpellier, France) were determined enzymatically using a 
spectrophotometric analyzer (Konelab 20, Thermo Scientific, MA, USA) (Lebret et al., 2011), within single assays. Glycogen was determined from glucose concentration after hydrolysis by amyloglucosidase.

\subsection{Tissue Antioxidant Capacity}

Total glutathione (T-glutathione), reduced glutathione (GSH) and oxidized disulphide glutathione (GSSG) contents were enzymatically analyzed (Griffith, 1980) in LM and the liver (duplicates) sampled within $30 \mathrm{~min}$ p.m. Briefly, each sample (100 mg) was homogenized in $2 \mathrm{~mL}$ ice-cold 5 -sulfosalicylic acid $(5 \% \mathrm{w} / \mathrm{v})$ and centrifuged for $5 \mathrm{~min}$ at 10 $000 \mathrm{~g}$ at $4^{\circ} \mathrm{C}$. The supernatants were collected and analyzed using a microplate reader (Thermo-Labsystems, Franklin, MA). The GSH content was calculated by subtracting $2 \times$ GSSG from T-glutathione. The amount of vitamin $\mathrm{E}$ was assessed in duplicates from LM lipid extracts after dilution of saponified lipids in hexane; samples were analyzed by normal phase HPLC (UP5SI-250/040, Interchim, Montluçon, France) fitted with a fluorimeter detector (excitation $292 \mathrm{~nm} / \mathrm{emission} 330 \mathrm{~nm}$ ) and with alpha-tocopherol concentrations as standards (Schüep \& Steiner, 1988). The results are expressed as $\mu \mathrm{g}$ vitamin E per $\mathrm{g}$ of tissue. The activities of catalase (CAT), total superoxide dismutase (SOD), glutathione reductase (GSH-Rx) and glutathione peroxidase (GSH-Px) were determined in LM (duplicates) sampled $30 \mathrm{~min}$ p.m. The CAT activity was measured by spectrometry at $240 \mathrm{~nm}$ (Uvikon Bio-Tek apparatus; Secomam, Alès Cedex, France) following the decrease in $\mathrm{H}_{2} \mathrm{O}_{2}$ concentration at $25^{\circ} \mathrm{C}$ (Young, Rosenvold, Stagsted, Nielsen, \& Andersen, 2005). Total SOD activity was measured at $450 \mathrm{~nm}$ by the inhibition of the xanthine/xanthine oxidase-mediated oxidation of cytochrome c, using a dedicated kit and the microplate reader. Activities of glutathione reductase (GSH-Rx; Massey \& William, 1965) and glutathione peroxidase (GSH-Px; Esworthy, Chu, \& Doroshow, 2001) were assessed at $37^{\circ} \mathrm{C}$ using the spectrophotometric 
analyzer described above by following NADPH decrease at $340 \mathrm{~nm}$ absorbance. Protein content was measured (duplicates) in the homogenates (Bradford, 1976) to calculate specific activities.

\subsection{Protein and Lipid Oxidation}

To evaluate the oxidative stability of muscle lipids at slaughter, the TBARS indexes were determined from LM samples taken 30 min p.m. and submitted for various incubation times $(0,60,120,180$ and $240 \mathrm{~min})$ at $37^{\circ} \mathrm{C}$ to force chemical oxidation induced by iron trichloride and sodium ascorbate (Kornbrust \& Mavis, 1980). The TBARS concentration was determined in duplicates and expressed in $\mu \mathrm{g}$ of malondialdehyde (MDA) produced per $\mathrm{g}$ of tissue. Protein carbonyls as indicative of protein oxidation and thiols contents were assessed in duplicates in total muscle proteins after 1,4 and 7 days of ageing on LM samples stored at $76^{\circ} \mathrm{C}$, following the methods described by Mercier, Gatellier, Viau, Rémignon, \& Rennerre (1998) and Morzel, Gatellier, Sayd, Renerre, \& Laville (2006). Carbonyls were expressed as nmoles of 2,4- dinitrophenylhydrazine (DNPH) incorporated per mg of protein, and free thiols were expressed as nmoles per mg of protein (Biuret method, Gornal, Bardawill, \& David, 1949), using an extinction coefficient of $14.0 \mathrm{mM}^{-1} \mathrm{~cm}^{-1}$.

\subsection{Statistics}

Data were analyzed by variance analysis (ANOVA) using the SAS Software's general linear model (GLM) procedure (SAS Cary NC, NY, USA). Diet, slaughter batch and their interaction were included in the model as fixed effects. Another model including the same fixed effects and using the initial BW as a covariate was also considered. Contrasts between dietary groups (CONT vs. Met3, CONT vs. Met5, and Met3 vs. Met 5, respectively) were determined from ANOVA. A $P$-value less than 0.05 was considered significant, and $0.05<P$ 
$\leq 0.10$ was considered a trend. Means per dietary group were calculated, and data are included in Tables and Figure. Chi-square tests were used to compare frequency of meat quality defects between dietary groups. Pearson's correlation coefficients between meat quality traits were calculated across all experimental pigs.

\section{Results}

\subsection{Growth Performance and Carcass Traits}

Average daily gain, daily feed intake and FCR were not different between dietary treatments (Table 2). The effect of initial BW (considered a covariate) was not significant $(P \geq 0.10)$ and did not modify the effect of dietary treatment on these traits. Lipid deposition was similar between treatments whether it was estimated by backfat thickness gain during the dietary trial's fourteen days, the weight of the entire perirenal fat or the proportion of dissectible backfat in pigs at slaughter. At the same BW and age at slaughter, the hot carcass weight, carcass dressing, lean meat content and carcass composition determined by the proportions of wholesale cuts did not differ between dietary groups.

\subsection{Muscle Biochemical Composition}

Met-supplemented diets did not affect the LM's water, protein or myoglobin contents, but intramuscular fat content was lower $(-0.23$ percentage point, $\mathrm{P}=0.04)$ in Met5 pigs than in CONT and Met3 pigs (Table 3). The glycolytic potential used as a surrogate for muscle glycogen content at the time of slaughter also tended to be lower $(\mathrm{P}=0.06)$ in $\mathrm{LM}$ of the Met5 pigs when compared with that of the CONT pigs. No significant differences were observed between Met3 and CONT pigs in these LM traits.

\subsection{Tissue Antioxidant Capacity}


Total (T-glutathione), reduced (GSH) and oxidized (GSSG) glutathione contents were greater $(\mathrm{P}<0.01)$ in the LM of Met5 pigs than in that of CONT pigs and of Met3 pigs, but they were similar in Met3 and CONT pigs (Table 3). The ratio of GSH to GSSG tended to be lower ( $\mathrm{P}<$ 0.10) in Met5 pigs than in CONT pigs, and the Met3 pigs exhibited an intermediate value that did not significantly differ from the two other groups. No significant differences were observed between dietary treatments for the amount of vitamin $\mathrm{E}$ or for the activities of GSHPx, GSH-Rx, SOD and catalase in the LM. Dietary Met supplementations did not change the glutathione contents (total amount, oxidized or reduced form) in the liver (Table 4).

\subsection{Lipids and Protein Oxidation}

Protein carbonyls and thiol contents in the LM were similar for the three dietary treatments when assessed at 1 day p.m. (Table 3) or at 4 or 7 days p.m. (data not shown). The TBARS content of LM at slaughter (i.e. $\mathrm{t}=0 \mathrm{~min}$ ) was lower in the Met5 group than in the CONT groups $(\mathrm{P}=0.021)$ and tended to be lower in the Met3 group than in the CONT group $(\mathrm{P}=$ 0.067) whereas Met3 and Met5 groups exhibited similar TBARS contents $(\mathrm{P}=0.61)$ at this time (Figure 1). After $60 \mathrm{~min}$ of induced chemical oxidation, TBARS content still tended to be lower in the Met5 group than in the CONT group $(\mathrm{P}=0.082)$ but did not differ between the Met3 and Met5groups or between the Met3 and CONT groups. Afterward, TBARS content did not significantly differ between the three dietary treatments.

\subsection{Meat Quality Traits}

At 30 min p.m., the $\mathrm{pH}$ value $(\mathrm{P}=0.06)$ tended to be higher in the $\mathrm{LM}$ of Met5 pigs than in that of CONT pigs, but the $\mathrm{pH}$ of Met3 pigs after 30 min was intermediate and not significantly different from that of the Met5 and CONT groups (Table 5). At $24 \mathrm{~h} \mathrm{p.m.,} \mathrm{the}$ LM of Met5 pigs exhibited a higher $\mathrm{pH}$ than that that found in CONT and Met3 pigs, but 
Met3 pigs and CONT pigs had a similar LM pH after $24 \mathrm{~h}$. Moreover, the frequency of low quality meat, i.e. pigs exhibiting either trend or actual PSE or acid meat defects in LM, was numerically lower in the Met5 group than in the CONT group (26 vs. $53 \%, \mathrm{P}=0.13$ ). The frequency of low quality meat in Met3 pigs fell between those of CONT or Met5 pigs. At 4 and 7 days p.m., loin meat from Met5 pigs tended to exhibit lower drip loss than meat from CONT pigs $(\mathrm{P} \leq 0.09)$ and Met 3 pigs $(\mathrm{P}<0.03)$ whereas Met3 and CONT pigs' drip losses were similar. The LM's color was also influenced by dietary Met level, with meat from Met5 pigs showing lower $\mathrm{C}^{*}$ and $\mathrm{h}^{\circ}$ values at day $1(\mathrm{P}<0.05)$ and lower $\mathrm{C}^{*}$ at day $4(\mathrm{P}=$ 0.003) than meat from the CONT group and a tendency for lower values of these color coordinates when compared with Met3 pigs $(\mathrm{P} \leq 0.10)$. At day $7, \mathrm{~L}^{*}$ and $\mathrm{C}^{*}$ values were significantly lower $(\mathrm{P} \leq 0.05)$, and $\mathrm{h}^{\circ}$ value tended to decrease $(\mathrm{P}=0.09)$ in the $\mathrm{LM}$ from Met5 in comparison to that of CONT pigs, and the $C^{*}$ value was lower in the Met5 pigs than in the Met3 pigs $(\mathrm{P}=0.02)$. No significant differences in meat color parameters at 1,4 or 7 days p.m. were found between Met3 and CONT pigs.

Similar to what was found in the loin, the $\mathrm{pH}$ at $24 \mathrm{~h}$ was significantly higher in the $\mathrm{SM}$ and GM muscles $(\mathrm{P}<0.01)$ and tended to be higher in the GS and AD muscles $(\mathrm{P}<0.10)$ of the Met5 pigs than in those of the CONT fed pigs (Table 6). The $\mathrm{pH}$ at $24 \mathrm{~h}$ was also significantly higher in the SM and GM of Met5 pigs than in the Met3 pigs. In the four ham muscles, the pH at $24 \mathrm{~h}$ did not significantly differ between Met3 and CONT pigs. Color parameters ( $\mathrm{L}^{*}, \mathrm{C}^{*}$ and $\mathrm{h}^{\circ}$ ) of the GS muscle at 1 day p.m. did not differ between the three dietary treatments. WHC increased in the Met3 and Met5 groups, compared to the CONT group $(\mathrm{P} \leq 0.05)$, but no difference was observed between the Met3 and Met5 groups. Finally, the MQI was improved in the Met3 and Met5 groups in a dose-dependent manner, compared to the CONT group. 


\section{Discussion}

Methionine (Met) is recognized as one as the most toxic AAs among those involved in protein synthesis, with hyper-methionemia leading to hepatic dysfunction, physiological disorders, and eventual death in laboratory animal models (Dever \& Elfarra, 2010). In the present study, neither death nor impairment of growth performance was observed during the test period for pigs fed 3 or 5 times the level of Met needed to achieve an optimal lean gain. In pigs, a large excess (4 times the requirement) of dietary Met supply for 100 days may reduce feed intake and growth rate (Fau, Delhomme, Bourdon, \& Rérat, 1980) whereas a moderate excess of Met (0.5 to 2 times) for up to 100 days did not modify growth performance (Fau et al., 1980; Edmonds, Gonyou, \& Baker, 1987a; Edmonds \& Baker, 1987b). In the present study, feed intake and growth rate were not modified by the excess of dietary Met in the form of HMTBA provided at 3 or 5 times over the growth needs. Body composition and the weight of the liver, the primary organ involved in Met metabolism, were also similar between dietary treatments. The greater amount of muscle T-glutathione when pigs were fed 5 times the Met level of the control diet suggests that the trans-methylation and trans-sulfuration pathways may have functioned as a Met detoxification pathway (Dever \& Elfarra, 2010). Indeed, increased amounts of ingested Met in pigs have been shown to proportionally induce the activity of methionine adenosyltransferase, an enzyme that catalyzes the first stage of the transmethylation pathway of Met into glutathione (Fau et al., 1980). This finding suggests that the body seems to avoid any deleterious excess of homocysteine that could result from Met excess (Garlick, 2006) by converting Met into cysteine and then glutathione. In agreement with our results, feeding low-birth-weight pigs with supplemental L-Met above the standard requirement (standard ileal digestibility (SID) of total sulfur amino acids (TSAA)/lysine (Lys) $=0.68$ ) all along their growing and finishing periods also led to a greater amount of muscular T-glutathione, compared to a control group (SID TSAA/Lys $=0.58$ ) (Li et al., 2017), but in 
this situation, the benefit on muscle glutathione content was observed only with twice the LMet level in the diet ( 0.15 vs. $0.07 \%$ in diet of control pigs).

The liver has been identified as the central site of inter-organ GSH homeostasis (Ookhtens \& Kaplowitz, 1998). In our study, supplemental dietary Met did not affect the hepatic glutathione system, suggesting that GSH may be exported from the liver to extra-hepatic tissues, such as muscles, to reduce ROS's deleterious effects (Richie et al., 2004). Indeed, the higher GSH and GSSG levels suggest a higher muscle detoxification capacity in response to supplementary dietary Met. In support of this result, TBARS levels in LM at slaughter were reduced by $28 \%$ in Met5-supplemented pigs, compared to CONT pigs, and this benefit remained after $60 \mathrm{~min}$ of induced chemical oxidation. This difference can only partly be explained by the $14 \%$ lower lipid content in LM of Met5 pigs compared to CONT pigs, suggesting an actual influence of dietary Met supplementation on the level of oxidation processes in pig muscle.

Conversely, supplementary dietary Met did not affect other antioxidant systems, such as vitamin E content and enzyme activities in muscle. The loin muscle Myoglobin content was not affected, either. Myoglobin content and antioxidant enzymes activity, especially that of SOD, are the main factors controlling p.m. protein oxidation in pork (Promeyrat et al., 2011). The lack of effects of dietary Met supplementation on LM protein oxidation, when assessed by the free thiols groups and carbonyl content, a sensitive indicator of cells exposure to oxygen radicals (Mercier et al., 1998), is then fully consistent. In agreement with our results, Li et al. (2017) reported a lower malondialdehyde content in the LM of pigs fed extra L-Met during growing and finishing periods and observed no effects of dietary Met supplementation on muscle protein carbonyls and GSH-Px and SOD activities. Moreover, Met supplementation at 5 times the level of $\mathrm{CON}$ was associated with a tendency of reduced lipid content and glycolytic potential (GP) in the LM. Thus, the increased dietary Met supply's 
effect on the biochemical composition of muscle was opposite the effect of dietary Met deficiency, which resulted in a greater muscle lipid content (Castellano et al., 2015) and a higher GP (Conde-Aguilera et al., 2014), compared with balanced diets. Taken together, these findings suggests that dietary Met level may change muscle energy metabolism, with lower energy stored under lipids or glycogen forms in the muscle when pigs were fed Metsupplemented diets.

Although muscle lipid content had been positively associated with pork sensory quality, the degree of difference between the Met5 and CON groups remained small, and for this range of lipid content, it is unlikely to induce differences in consumers' perception of meat (Lebret \& Faure, 2015). Conversely, the greatest dose of Met supplementation induced significant effects on the ultimate $\mathrm{pH}$ in loin and ham muscles (up to $+0.15 \mathrm{pH}$ unit). This effect could be the result of the lower GP observed in Met5 pigs, these two traits being highly correlated in the present study $(\mathrm{r}=-0.81, \mathrm{P}<0.001)$ in agreement with the literature's data (Monin \& Sellier, 1985). In addition, the lower meat drip loss was observed in Met5 pigs, which might be explained by higher values of $\mathrm{pH} 30 \mathrm{~min}(\mathrm{r}=-0.65 \mathrm{P}<0.001)$ and $\mathrm{pH} 24 \mathrm{~h}(\mathrm{r}=-0.64$ $\mathrm{P}<0.001$ ) according to the well-known relationships between these traits (Warriss, 2010). The Met5 pigs' lower drip loss might also be explained by the changes observed in muscle antioxidant/oxidative parameters, which could include limited alterations of lipid membranes and reduced drip, two responses that have been also observed in meat from pigs fed vitamin E-supplemented diets (Lebret 2008). In agreement with the present study, feeding low-birthweight pigs with doses of L-Met above the Met requirement from $40 \mathrm{~kg}$ up to $100 \mathrm{~kg} \mathrm{BW}$ increased the ultimate $\mathrm{pH}$ value and lowered drip loss in loin meat (Li et al., 2017). Moreover, a higher ultimate $\mathrm{pH}$ value has been observed in meat from chicken fed with HMTBAsupplemented diets (Mercier et al., 2009). Thus, results of the present study showed a clear improvement of the technological quality of pork induced by extra-dietary Met 
supplementation, which is supported by the greater MQI in the ham as soon as Met supplementation corresponds to three times the growth requirement and the lower frequency of defected loin meat. Altogether, these changes are particularly interesting for the pork industry. Indeed, the ultimate $\mathrm{pH}$ of $\mathrm{SM}$ is a major determinant of technological quality and one of the few and sometimes the only quality indicator considered for the sorting of hams in the pork industry (Lebret \& Faure 2015). Finally, the highest Met supplementation level modified the loin color parameters and their variations during meat ageing. Lower lightness was especially observed at 7 days p.m., and lower saturation (chroma) all along ageing duration and lower hue angle were especially observed at 1 and 7 days p.m. The lower hue of Met5 pigs (indicating redder meat) is in agreement with the higher $h^{\circ}$ value of meat conversely reported in chickens fed Met-deficient diets, compared to the control group (Conde-Aguilera et al., 2016b). This finding suggests a lower oxidation of myoglobin with the Met-supplemented diet, which could result from the greater muscle protection toward oxidation as reflected by the higher muscle glutathione and TBARs levels. Altogether, these changes are favorable traits for the appearance of meat perceived by consumers, which is a major quality dimension for intention to purchase pork (Warriss, 2010).

\section{Conclusion}

Dietary Met supplementation as HMTBA at doses three or five times above the recommendations for growth during the last fourteen days before slaughter did not affect pig performance or carcass composition. The highest Met supplementation increased glutathione concentrations and decreased TBARS levels in muscle at slaughter stage. This change was accompanied by an increase in the meat's (loin, ham) ultimate $\mathrm{pH}$, a decrease in drip loss and better meat quality index. The highest Met supplementation also influenced loin meat color with decreased hue angle of fresh meat and reduced lightness after 7 days of ageing. 
Consequently, this flash dietary supplementation of methionine five times above Met requirements improved several indicators of the technological quality and of the appearance of meat, the two major qualitative dimensions for the stakeholders of the pork industry and consumers, without affecting growth performance or the carcasses' commercial value.

\section{Acknowledgements}

The authors thank the staff of INRA experimental farm and slaughterhouse (J Delamarre, P Roger, H Demay, M Alix, J Liger, J F Rouault; UEPR, 35590 Saint-Gilles, France) and INRA laboratories (S Tacher, S Daré-Michelot, F Mayeur-Nickel, N Bonhomme; PEGASE, F35590 Saint-Gilles) involved in this study for their excellent assistance. This work was supported by ADISSEO company and INRA. 


\section{References}

AOAC. (1990). Official methods of analysis, 15th ed. Assoc. Offic. Anal. Chem., Arlington, VA.

Agostini, P. S., Dalibard, P., Mercier, Y., Van der Aar, P., \& Van der Klis, J. D. (2015).

Comparison of methionine sources around requirement levels using a methionine efficacy method in 0 to 28 day old broilers. Poultry Science, 95, 560-569.

Bradford, M. M. (1976). A rapid and sensitive method for the quantitation of microgram quantities of protein utilizing the principle of protein-dye binding. Analytical Biochemistry, 7 (72), 248-254.

Castellano, R., Perruchot, M. H., Conde-Aguilera, J. A., van Milgen, J., Collin, A., Tesseraud, S., Mercier, Y., \& Gondret, F. (2015). A methionine deficient diet enhances adipose tissue lipid metabolism and alters anti-oxidant pathways in young growing pigs. PLoS One, 10(7):e0130514.

Conde-Aguilera, J. A., Barea, R., Le Floc'h, N., Lefaucheur, L., \& van Milgen, J. (2010). A sulfur amino acid deficiency changes the amino acid composition of body protein in piglets. Animal, 4, 1349-1358.

Conde-Aguilera, J. A., Cobo-Ortega, C., Mercier, Y., Tesseraud, S., \& van Milgen, J. (2014). The amino acid composition of tissue protein is affected by the total sulfur amino acid supply in growing pigs. Animal, 8, 401-409.

Conde-Aguilera J.A., Lefaucheur L., Tesseraud S., Mercier Y., Le Floc'h N., \& van Milgen J. (2016a). Skeletal muscles respond differently when piglets are offered a diet $30 \%$ deficient in total sulfur amino acid for 10 days. European Journal of Nutrition, 55, 117-126. 
Conde-Aguilera, J. A., Cholet, J. C., Lessire, M., Mercier, Y., Tesseraud, S., \& van Milgen, J. (2016b). The level and source of free-methionine affect body composition and breast muscle traits in growing broilers. Poultry Science, 95, 2322-2331.

Daumas, G. (2008). Taux de muscle des pièces et appréciation de la composition corporelle des carcasses. Journées Recherche Porcine, Vol. 40. (pp. 61-68), Paris (France): INRAIFIP.

Dever, J. T., \& Elfarra, A. A. (2010). The biochemical and toxicological significance of hypermethionemia: new insights and clinical relevance. Expert Opinion on Drug Metabolism and Toxicology, 6, 1333-1346.

Esworthy, R. S., Chu, F. F., \& Doroshow, J. H. (2001). Analysis of glutathione-related enzymes. Current Protocols in Toxicology, 00:7.1:7.1.1-7.1.32.

Edmonds, M. S., Gonyou, H. W., \& Baker, D. H. (1987a). Effect of excess levels of methionine, tryptophan, arginine, lysine or threonine on growth and dietary choice in the pig. Journal of Animal Science, 65, 179-185.

Edmonds, M. S., \& Baker D.H. (1987b). Amino acid excesses for young pigs: effects of excess methionine, tryptophan, threonine or leucine. Journal of Animal Science, 64, 16641671.

Fau, D., Delhomme, B., Bourdon, D., \& Rérat, A. (1980). Enzymatic activities in the liver, and muscle nucleic acids, in swine receiving an unbalanced diet with an excess of methionine for 100 days. Comptes Rendus des Séances d'Académie des Sciences, 291, $565-568$

Folch, J., Lees, M., \& Stanley, G. H. S. (1957). A simple method for the isolation of total lipids from animal tissues. Journal of Biological Chemistry, 226, 497-509.

Garlick, P. J. (2006). Toxicity of methionine in humans. Journal of Nutrition, 136, 1722S$1725 \mathrm{~S}$ 
Gornall, A. G., Bardawill, C. J., \& David, M. M. (1949). Determination of serum proteins by means of the biuret reaction. The Journal of Biological Chemistry, 177(2), 751-766.

Griffith, O.W. (1980). Determination of glutathione and glutathione disulfide using glutathione reductase and 2-vinylpyridine. Analytical Biochemistry, 106, 207-212.

Hornsey, H. C. (1956). The colour of cooked cured pork. I. Estimation of the nitric oxidehaem pigments. Journal of the Science of Food and Agriculture, 7, 534540.

Huff-Lonergan, E., \& Lonergan, S.M. (2005). Mechanisms of waterholding capacity of meat: The role of postmortem biochemical and structural changes. Meat Science, 71, 194-204.

Kornbrust, D. J., \& Mavis, R. D. (1980). Microsomal lipid peroxidation. I. Characterization of the role of iron and NADPH. Molecular Pharmacology, 17(3), 400-407.

Lebret, B. (2008). Effects of feeding and rearing systems on growth, carcass composition and meat quality in pigs. Animal, 2, 1548-1558.

Lebret, B., Prunier, A., Bonhomme, N., Foury, A., Mormède, P., \& Dourmad, J. Y. (2011). Physiological traits and meat quality of pigs as affected by genotype and housing system. Meat Science, 88, 14-22.

Lebret, B. \& Faure, J. (2015). Pork and pork products : how to fulfill a variety of quality demands? INRA Productions Animales, 28, 111-114.

Li, Y., Zhang, H., Chen, Y. P., Ying, Z. X., Su, W. P., Zhang, L. L., \& Wang T. ( 2017). Effects of dietary 1-methionine supplementation on the growth performance, carcass characteristics, meat quality, and muscular antioxidant capacity and myogenic gene expression in low birth weight pigs. Journal of Animal Science, 95, 3972-3983.

Lund, M. N., Lametsch, R., Hviid, M. S., Jensen, O. N., \& Skibsted, L. H. (2007). HighOxygen Packaging Atmosphere Influences Protein Oxidation and Tenderness of Porcine longissimus dorsi during Chill Storage. Meat Science, 77, 295-303. 
Martin-Venegas, R., Geraert, P. A., \& Ferrer, R. (2006). Conversion of the Methionine Hydroxy Analogue DL-2-Hydroxy-(4-Methylthio) Butanoic Acid to Sulfur-Containing Amino Acids in the Chicken Small Intestine. Poultry Science, 85, 1932-1938.

Massey, V., \& Williams, C. H. Jr. (1965). On the reaction mechanism of yeast glutathione reductase. The Journal of Biological Chemistry, 240, 4470-4480.

Mercier, Y., Gatellier, P., Viau, M., Rémignon, H., \& Renerre, M. (1998). Effect of dietary fat and vitamin $\mathrm{E}$ on colour stability and on lipid and protein oxidation in turkey meat during storage. Meat Science, 48 (3-4), 301-318.

Mercier, Y., Berri, C., Baéza, E., Bordeau, T., Chartrin, P., Mercerand, F., \& Geraert, P. A. (2009). Improvement of muscle oxidative stability and processing yield in relation with dietary methionine sources. Proc. 98th Annual Meeting Poultry Science Association, Raleigh, USA. Abstr. 117.

Monin, G., Sellier, P., Ollivier, L., Goutefongea, R., \& Girard, J. P. (1981). Carcass characteristics and meat quality of halothane- negative and halothane- positive Piétrain pigs. Meat Science, 5, 413- 428.

Monin, G., \& Sellier P. (1985). Pork of low technological quality with a normal rate of muscle $\mathrm{pH}$ fall in the immediate postmortem period: The case of the Hampshire breed. Meat Science, 13, 49-63.

Morzel, M., Gatellier, P., Sayd, T., Renerre, M., \& Laville, E. (2006). Chemical oxidation decreases proteolytic susceptibility of skeletal muscle myofibrillar proteins. Meat Science, $73,536-543$.

Ookhtens, M., \& Kaplowitz N. (1998). Role of the liver in interorgan homeostasis of glutathione and cyst(e)ine. Seminars in Liver Disease, 18(4), 313-329. 
Promeyrat, A., Sayd, T., Laville, E., Chambon, C., Lebret, B., \& Gatellier P. (2011). Early post-mortem sarcoplasmic proteome of porcine muscle related to protein oxidation. Food Chemistry, 127, 1097-1104.

Richie, J. P. Jr., Komninou, D., Leutzinger, Y., Kleinman, W., Orentreich, N., Malloy, V., \& Zimmerman, J.A. (2004). Tissue glutathione and cysteine levels in methionine-restricted rats. Nutrition, 20, 800-805.Schüep, W., \& Steiner, K. (1988). Determination of alphatocopheryl acetate in feed premixes with HPLC. In : H.E. Kelmer (Ed), Analytical methods for vitamins and Carotenoids in feed, ROCHE Animal Nutrition and Health.

Schüep, W., \& Steiner, K. (1988). Determination of alpha-tocopheryl acetate in feed premixes with HPLC. In : H.E. Kelmer (Ed), Analytical methods for vitamins and Carotenoids in feed, ROCHE Animal Nutrition and Health.

Shahidi, F., Wanasundara, P. K. J. P. D. (1992). Phenolic antioxidants. Critical Reviews in Food Science and Nutrition, 32 (1), 67-103.

Swennen, Q., Geraert, P. A., Mercier, Y., Everaert, N., Stinckens, A., Willemsen, H., Li, Y., Decuypere, E., \& Buyse J. (2011). Effects of dietary protein content and 2-hydroxy-4methylthiobutanoic acid or DL-methionine supplementation on performance and oxidative status of broiler chickens. British Journal of Nutrition, 106, 1845-1854.

Tesseraud, S., Métayer-Coustard, S., Collin, A., \& Seiliez, I. (2009). Role of sulfur amino acids in controlling nutrient metabolism and cell functions: implications for nutrition. British Journal of Nutrition, 101, 1132-1139.

Tribout, T., \& Bidanel, J. P. (2000). Genetic parameters of meat quality traits recorded on Large White and French Landrace station-tested pigs in France. In C. Wenk, J. A. Fernandez, \& M. Dupuis (Eds.), EAAP, Vol. 100. (pp. 37-41). 
Vazquez-Anon, M., Bertin, G., Mercier, Y., Reznik, G., \& Roberton, J. L. (2017). Review of the chemistry, metabolism, and dose response of two supplemental methionine sources and the implications in their relative bioefficacy. World's Poultry Science Journal, 73, 1-12.

Warriss, P. D. (2010). Meat science $2^{\text {nd }}$ edition, an introductory text. CABI Publishing, Wallingford, UK. 234 p.

Young, J. F., Rosenvold, K., Stagsted, J., Nielsen, J. H., \& Andersen, H. J. (2005).

Significance of vitamin E supplementation, dietary content of polyunsaturated fatty acids, and preslaughter stress on oxidative status in pig as reflected in cell integrity and antioxidative enzyme activities in porcine muscle. Journal of Agricultural and Food Chemistry, 53, 745-749.

Zhang, H., Li, Y., \& Wang, T. (2015). Antioxidant capacity and concentration of redox-active trace mineral in fully weaned intrauterine growth retardation piglets. Journal of Animal Science and Biotechnology, 6, 48. 
Table 1. Composition of experimental diets

\begin{tabular}{|c|c|c|c|}
\hline Diet & CONT & Met3 & Met5 \\
\hline \multicolumn{4}{|c|}{ Ingredients $^{\text {a }}$ (g/kg as fed basis) } \\
\hline Maize & 661 & 661 & 661 \\
\hline Wheat & 100 & 100 & 100 \\
\hline Soybean meal 48 & 160 & 160 & 160 \\
\hline Wheat middlings & 10.0 & 5.0 & 0 \\
\hline Palm oil & 30 & 30 & 30 \\
\hline Calcium carbonate & 12.8 & 12.8 & 12.8 \\
\hline Dicalcium phosphate & 9.8 & 9.8 & 9.8 \\
\hline Vitamin/mineral premix ${ }^{\mathbf{b}}$ & 10 & 10 & 10 \\
\hline Salt & 4.0 & 4.0 & 4.0 \\
\hline L-Lys $\mathrm{HCl}$ & 2.2 & 2.2 & 2.2 \\
\hline L-Thr & 0.1 & 0.1 & 0.1 \\
\hline L-Trp & 0.4 & 0.4 & 0.4 \\
\hline DL-HMTBA & 0 & 5.0 & 10.0 \\
\hline \multicolumn{4}{|c|}{ 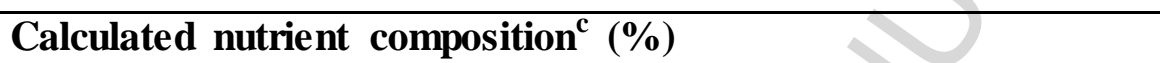 } \\
\hline Crude protein & 13.7 & 13.6 & 13.6 \\
\hline Crude Fat & 5.82 & 5.81 & 5.79 \\
\hline Ash & 4.80 & 4.78 & 4.76 \\
\hline Cellulose & 2.59 & 2.57 & 2.54 \\
\hline Net energy $(\mathrm{MJ} / \mathrm{kg})$ & 10.38 & 10.41 & 10.44 \\
\hline Lys $^{d}$ & 0.73 & 0.73 & 0.73 \\
\hline \multicolumn{4}{|l|}{ Met } \\
\hline TSAA & 0.45 & 0.83 & 1.27 \\
\hline $\mathrm{Thr}^{\mathrm{d}}$ & 0.46 & 0.46 & 0.46 \\
\hline $\operatorname{Trp}^{\mathrm{d}}$ & 0.13 & 0.13 & 0.13 \\
\hline $\operatorname{Arg}^{\mathrm{d}}$ & 0.80 & 0.79 & 0.79 \\
\hline $\mathrm{His}^{\mathrm{d}}$ & 0.35 & 0.35 & 0.35 \\
\hline $\mathrm{Ile}^{\mathrm{d}}$ & 0.54 & 0.53 & 0.53 \\
\hline $\mathrm{Leu}^{\mathrm{d}}$ & 1.24 & 1.23 & 1.23 \\
\hline$P h e^{d}$ & 0.64 & 0.64 & 0.64 \\
\hline Phe+Tyr ${ }^{d}$ & 1.11 & 1.11 & 1.10 \\
\hline $\mathrm{Val}^{\mathrm{d}}$ & 0.61 & 0.61 & 0.61 \\
\hline \multicolumn{4}{|l|}{ Analyzed (\%) } \\
\hline $\mathrm{Met}^{\mathrm{e}}$ & 0.20 & 0.59 & 1.02 \\
\hline $\mathrm{Cys}^{\mathrm{e}}$ & 0.25 & 0.24 & 0.25 \\
\hline
\end{tabular}

Abbreviation used: TSAA, total sulfur amino acid.

${ }^{\mathrm{a} C O N T}$, a control diet, Met3 and Met5, Methionine-supplemented diets

${ }^{b}$ Vitamins (/kg diet) A (7500 UI), D3 (1500 UI), E (20 UI), B1 (0.5 mg), K3 (1.0 mg), B2 (3.0 $\mathrm{mg})$, B5 (10.0 mg), B6 (1.0 mg), B12 $(0.015 \mathrm{mg})$, PP (1500 mg) and minerals iron $(80 \mathrm{mg})$, iodine $(0.50 \mathrm{mg})$, copper $(15 \mathrm{mg})$, manganese $(40 \mathrm{~g})$, zinc oxide $(80 \mathrm{mg})$ and sodium selenite $(0.25 \mathrm{mg})$ together with phytase (500 FTU). 
${ }^{\mathrm{c}}$ Calculated, adjusted for $86.3 \%$ of dry matter.

${ }^{\mathrm{d}}$ Calculated from the calculated ileal digestibility values of the ingredients, and adjusted for $86.3 \%$ of dry matter.

${ }^{\mathrm{e}}$ Analysed methionine equivalent (Total Met + HMTBA) and cystine levels (Agostini et al., 2015) 
Table 2. Effects of dietary Met supplementation on performance of finisher pigs ${ }^{\text {a }}$

\begin{tabular}{lccccc}
\hline & CONT & Met3 & Met5 & Rsd & $\begin{array}{c}\text { P-value } \\
\text { Diet }\end{array}$ \\
& & & & & \\
Growth performance & & & & & \\
Initial body weight (BW), kg & 105.5 & 102.6 & 105.1 & 6.1 & 0.31 \\
Final (slaughter) BW, kg & 124.5 & 121.1 & 123.0 & 6.8 & 0.35 \\
Age at slaughter, d & 173.1 & 172.7 & 172.9 & 0.9 & 0.44 \\
Average daily gain, kg/d & 1.33 & 1.32 & 1.28 & 0.21 & 0.65 \\
Average daily feed intake, kg/d & 3.49 & 3.51 & 3.39 & 0.31 & 0.46 \\
Food conversion ratio & 2.33 & 2.36 & 2.36 & 0.23 & 0.80 \\
Backfat gain, mm & 3.3 & 3.3 & 3.0 & 1.7 & 0.77 \\
Body and carcass traits & & & & & \\
Perirenal fat, kg & 1.71 & 1.57 & 1.53 & 0.35 & 0.38 \\
Liver weight, kg & 1.99 & 1.89 & 2.00 & 0.24 & 0.46 \\
Hot carcass weight, kg & 99.5 & 97.3 & 98.2 & 6.2 & 0.59 \\
Carcass dressing, \% & 79.8 & 80.4 & 79.9 & 1.6 & 0.65 \\
Carcass drip loss, \% & 2.29 & 2.22 & 2.22 & 0.15 & 0.39 \\
Carcass composition, \% ${ }^{\text {b }}$ & & & & & \\
$\quad$ Loin & 27.3 & 27.2 & 27.2 & 1.0 & 0.94 \\
$\quad$ Ham & 26.3 & 26.6 & 26.3 & 0.8 & 0.55 \\
$\quad$ Shoulder & 24.6 & 24.8 & 25.0 & 0.7 & 0.26 \\
Belly & 12.8 & 12.8 & 12.7 & 0.5 & 0.94 \\
$\quad$ Backfat & 6.4 & 6.2 & 6.2 & 0.8 & 0.70 \\
Lean meat content, \% ${ }^{\mathrm{c}}$ & 60.1 & 60.6 & 60.5 & 1.9 & 0.86 \\
\hline Pigs were fed
\end{tabular}

${ }^{\text {a}}$ Pigs were fed either a control diet (CONT) adequate in Met or a HMTBA-supplemented diets with calculated value of Met being respectively, 3 times (Met3 group) or 5 times greater (Met5 group), than that in the CONT diet. Results are presented as means for the 3 dietary treatments ( $\mathrm{n}=15 \mathrm{pigs} /$ group) and Residual standard deviation (Rsd) of the analysis of variance. Performance was calculated on the 14 days of the dietary trial.

${ }^{\mathrm{b}}$ Calculated as relative percentage of the cold right side.

${ }^{\mathrm{c}}$ Calculated from the proportion of retail cuts . 
Table 3. Effects of dietary Met supplementation on biochemical traits of longissimus lumborum muscle ${ }^{a}$

\begin{tabular}{lcccccccc}
\hline & CONT & Met3 & Met5 & Rsd & \multicolumn{3}{c}{ P-values } \\
\\
\end{tabular}

${ }^{\text {a }}$ Pigs were fed either a control diet (CONT) adequate in Met or a HMTBA-supplemented diets with calculated value of Met being respectively, 3 times (Met3 group) or 5 times greater (Met5 group), than that in the CONT diet. Results are presented as means for the 3 dietary treatments ( $\mathrm{n}=15 \mathrm{pigs} /$ group) and Residual standard deviation (Rsd) of the analysis of variance.

${ }^{\mathrm{b}} \mathrm{P}$ values of diet effect in ANOVA, and of contrasts calculated between experimental groups. ${ }^{\mathrm{c}}$ Abbreviations used: T-glutathione = total glutathione; $\mathrm{GSH}=$ reduced glutathione; GSSG = oxidized glutathione; GSH-Px = glutathione peroxidase; GSH-Rx = glutathione reductase; SOD $=$ superoxide dismutase

${ }^{\mathrm{d}}$ DNPH : Dinitrophenyl-hydrazine 
Table 4. Effects of dietary Met supplementation on liver glutathione system ${ }^{\mathrm{a}}$

\begin{tabular}{|c|c|c|c|c|c|}
\hline & CONT & Met3 & Met5 & Rsd & $P$-value \\
\hline & & & & & Diet \\
\hline T-glutathio $\mathrm{ne}^{\mathrm{b}}, \mathrm{nmol} / \mathrm{g}$ & 2336 & 2324 & 2330 & 537 & 0.85 \\
\hline GSH, nmole/g & 1924 & 1895 & 1831 & 444 & 0.85 \\
\hline GSSG, nmole/g & 830 & 860 & 799 & 237 & 0.73 \\
\hline GSH:GSSG ratio & 2.37 & 2.27 & 2.37 & 0.45 & 0.48 \\
\hline
\end{tabular}

${ }^{\text {a } P i g s ~ w e r e ~ f e d ~ e i t h e r ~ a ~ c o n t r o l ~ d i e t ~(C O N T) ~ a d e q u a t e ~ i n ~ M e t ~ o r ~ a ~ H M T B A-s u p p l e m e n t e d ~ d i e t s ~}$ with calculated value of Met being respectively, 3 times (Met3 group) or 5 times greater (Met5 group), than that in the CONT diet. Results are presented as means for the 3 dietary treatments ( $\mathrm{n}=15 \mathrm{pigs} /$ group) and Residual standard deviation (Rsd) of the analysis of variance.

${ }^{\mathrm{b}} \mathrm{T}$-glutathione = total glutathione; $\mathrm{GSH}=$ reduced glutathione; $\mathrm{GSSG}=$ oxidized glutathione 
Table 5. Effects of dietary Met supplementation on loin quality traits ${ }^{\text {a }}$

\begin{tabular}{|c|c|c|c|c|c|c|c|c|}
\hline & \multirow[t]{3}{*}{ CONT } & \multirow[t]{3}{*}{ Met3 } & \multirow[t]{3}{*}{ Met5 } & \multirow[t]{3}{*}{ Rsd } & \multicolumn{4}{|c|}{$P$-values ${ }^{b}$} \\
\hline & & & & & \multirow[t]{2}{*}{ Diet } & \multirow{2}{*}{$\begin{array}{c}\text { Met3 } \\
\text { vs. } \\
\text { CONT }\end{array}$} & \multirow{2}{*}{$\begin{array}{c}\text { Met5 } \\
\text { vs. } \\
\text { CONT }\end{array}$} & \multirow{2}{*}{$\begin{array}{c}\text { Met5 } \\
\text { vs. } \\
\text { Met3 }\end{array}$} \\
\hline & & & & & & & & \\
\hline pH 30 min p.m. ${ }^{c}$ & 6.13 & 6.19 & 6.22 & 0.14 & 0.17 & 0.21 & 0.06 & 0.53 \\
\hline pH 24 h p.m. & 5.55 & 5.57 & 5.66 & 0.11 & 0.01 & 0.58 & 0.006 & 0.03 \\
\hline Drip loss, $1-4$ d p.m. & 6.0 & 6.5 & 4.5 & 2.4 & 0.06 & 0.56 & 0.09 & 0.02 \\
\hline Drip loss, $1-7$ d p.m. & 7.9 & 8.2 & 6.3 & 2.4 & 0.06 & 0.72 & 0.06 & 0.03 \\
\hline \multicolumn{9}{|l|}{ Color, d1 } \\
\hline $\mathrm{L}^{*}$ & 52.3 & 52.1 & 50.4 & 3.2 & 0.21 & 0.87 & 0.11 & 0.15 \\
\hline $\mathrm{C}^{*}$ & 9.6 & 8.8 & 7.7 & 1.6 & 0.006 & 0.17 & 0.001 & 0.05 \\
\hline $\mathrm{h}^{\circ}$ & 28.5 & 27.7 & 24.7 & 4.9 & 0.09 & 0.64 & 0.04 & 0.10 \\
\hline \multicolumn{9}{|l|}{ Color, d4 } \\
\hline $\mathrm{L}^{*}$ & 53.5 & 53.1 & 52.2 & 2.4 & 0.29 & 0.66 & 0.13 & 0.28 \\
\hline $\mathrm{C}^{*}$ & 11.1 & 10.5 & 9.6 & 1.3 & 0.01 & 0.21 & 0.003 & 0.07 \\
\hline $\mathrm{h}^{\circ}$ & 39.8 & 39.8 & 40.0 & 4.2 & 0.97 & 0.95 & 0.82 & 0.86 \\
\hline \multicolumn{9}{|l|}{ Color, d7 } \\
\hline $\mathrm{L}^{*}$ & 56.1 & 55.5 & 53.6 & 3.3 & 0.11 & 0.73 & 0.05 & 0.10 \\
\hline $\mathrm{C}^{*}$ & 10.8 & 10.8 & 9.5 & 1.5 & 0.02 & 0.99 & 0.02 & 0.02 \\
\hline $\mathrm{h}^{\circ}$ & 51.5 & 48.4 & 47.4 & 6.6 & 0.22 & 0.20 & 0.09 & 0.69 \\
\hline
\end{tabular}

${ }^{\mathrm{a}}$ Pigs were fed either a control diet (CONT) adequate in Met or a HMTBA-supplemented diets with calculated value of Met being respectively, 3 times (Met3 group) or 5 times greater (Met5 group), than that in the CONT diet. Results are presented as means for the 3 dietary treatments ( $\mathrm{n}=15 \mathrm{pigs} /$ group) and Residual standard deviation (Rsd) of the analysis of variance.

${ }^{\mathrm{b}} \mathrm{P}$ values of diet effect in ANOVA, and of contrasts calculated between experimental groups.

${ }^{\mathrm{c}}$ Abbreviations used: $\mathrm{d}=$ day; $\mathrm{p} . \mathrm{m}$. = postmortem 
Table 6. Effects of dietary Met supplementation on ham quality traits ${ }^{\text {a }}$

\begin{tabular}{|c|c|c|c|c|c|c|c|c|}
\hline & \multirow[t]{2}{*}{ CONT } & \multirow[t]{2}{*}{ Met3 } & \multirow[t]{2}{*}{ Met5 } & \multirow[t]{2}{*}{ Rsd } & \multicolumn{4}{|c|}{$P$-values ${ }^{\mathrm{b}}$} \\
\hline & & & & & Diet & $\begin{array}{c}\text { Met3 } \\
\text { vs. } \\
\text { CONT }\end{array}$ & $\begin{array}{c}\text { Met5 } \\
\text { vs. } \\
\text { CONT }\end{array}$ & $\begin{array}{c}\text { Met5 } \\
\text { vs. } \\
\text { Met3 }\end{array}$ \\
\hline \multicolumn{9}{|l|}{$\mathrm{pH}, 24$ h p.m. ${ }^{\mathrm{c}}$} \\
\hline Semimembranosus & 5.61 & 5.68 & 5.77 & 0.14 & 0.007 & 0.20 & 0.002 & 0.05 \\
\hline Gluteus medius & 5.55 & 5.59 & 5.69 & 0.14 & 0.02 & 0.47 & 0.006 & 0.04 \\
\hline Gluteus superficialis & 5.66 & 5.75 & 5.76 & 0.16 & 0.17 & 0.14 & 0.08 & 0.78 \\
\hline Adductor & 5.77 & 5.85 & 5.91 & 0.23 & 0.23 & 0.38 & 0.09 & 0.39 \\
\hline \multicolumn{9}{|c|}{ Technological quality traits of Gluteus superficialis, 24 h p.m. } \\
\hline $\mathrm{L}^{*}$ & 49.1 & 47.7 & 48.0 & 2.6 & 0.35 & 0.17 & 0.28 & 0.76 \\
\hline $\mathrm{C}^{*}$ & 12.5 & 12.8 & 11.8 & 1.7 & 0.34 & 0.73 & 0.29 & 0.16 \\
\hline $\mathrm{h}^{\circ}$ & 28.0 & 27.0 & 27.0 & 2.9 & 0.54 & 0.34 & 0.33 & 0.99 \\
\hline WHC, point & 16.8 & 19.7 & 19.8 & 4.0 & 0.06 & 0.05 & 0.04 & 0.90 \\
\hline $\begin{array}{l}\text { Meat Quality Index, } \\
\text { point }\end{array}$ & 11.2 & 12.6 & 13.5 & 1.9 & 0.004 & 0.05 & 0.001 & 0.12 \\
\hline
\end{tabular}

${ }^{a}$ Pigs were fed either a control diet (CONT) adequate in Met or a HMTBA-supplemented diets with calculated value of Met being respectively, 3 times (Met3 group) or 5 times greater (Met5 group), than that in the CONT diet. Results are presented as means for the 3 dietary treatments ( $\mathrm{n}=15 \mathrm{pigs} /$ group) and Residual standard deviation (Rsd) of the analysis of variance.

${ }^{b} \mathrm{P}$ values of diet effect in ANOVA, and of contrasts calculated between experimental groups.

${ }^{\mathrm{c}}$ Abbreviation used: p.m. = postmortem; WHC : water holding capacity 
Figure 1. Lipid oxidation in Longissimus lumborum muscle according to the dietary group

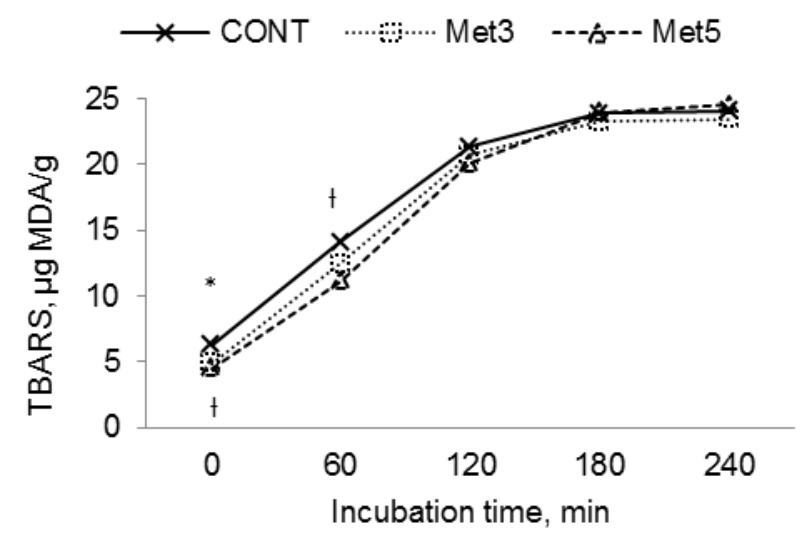

Thiobarbituric acid reactive substances (TBARS) were assessed after 0, 60, 120, 180 or 240 minutes of incubation in oxidizing conditions, and values expressed in $\mu \mathrm{g}$ of malondialdehyde (MDA) per g of muscle.

Pigs were fed either a control diet (CONT) adequate in Met or a HMTBA-supplemented diets with calculated value of Met being respectively, 3 times (Met3) or 5 times greater (Met5), than that in the CONT diet.

* : P $<0.05$ for contrast between Met 5 and CONT group at $0 \mathrm{~min} ; \mathrm{t}: \mathrm{P} \leq 0.10$ for contrast between Met 3 and CONT group at $0 \mathrm{~min}$, and for contrast between Met5 and CONT group at $60 \mathrm{~min}$. At other incubation times, $\mathrm{P}$ values of contrasts between treatments did not reach significance $(\mathrm{P}>0.10)$. 


\section{Highlights}

- Methionine supply over the requirements does not alter pig growth or carcass traits

- Short-term dietary methionine supply improves muscle glutathione content in pigs

- Ultimate $\mathrm{pH}$ is increased in the loin and ham of pigs fed supplementary methionine

- Dietary methionine supplementation improves ham's technological quality 